No. 20

Article 12

Number 1 (2015)

From Dada to Infra-noir: Dada, Surrealism, and

Romania

\title{
Cubomania: Gherasim Luca and Non-Oedipal Collage
}

Krzysztof Fijalkowski Norwich University of the Arts

Copyright (C) 2015 Krzysztof Fijalkowski

\section{Recommended Citation}

Fijalkowski, Krzysztof. "Cubomania: Gherasim Luca and Non-Oedipal Collage." Dada/Surrealism 20 (2015): n. pag. Web.

Hosted by Iowa Research Online

This Theme Essay is brought to you for free and open access by Iowa Research Online. It has been accepted for inclusion in Dada/Surrealism by an authorized administrator of Iowa Research Online. For more information, please contact lib-ir@uiowa.edu. 


\title{
Cubomania: Gherasim Luca and Non-Oedipal Collage Krzysztof Fijalkowski
}

\author{
'La cubomanie nie'
}

Gherasim Luca

For nearly all Anglophone audiences of surrealism, devotees and scholars alike, the voice of Gherasim Luca (1913-1994) remains to be discovered. As a member of the short-lived surrealist group active in Bucharest between 1940 and 1947 - one of the most fervid chapters in the story of the international movement but also one of its least known - and in post-war Paris, as a lone poet of incantations of the void and its negation, close to André Breton's surrealist circle without being drawn into it, Luca's status could be seen as that of a troubling, liminal figure. This is no more than he might have wished, yet among those who do know his work there are many who consider it to be some of the most original of its time. ${ }^{1}$

1 The principal reception of Luca's work has been, naturally enough, in Romania and France (and often by Romanian scholars publishing in French). The three most comprehensive sources on Luca are in French: Dominique Carlat's Gherasim Luca l'intempestif of 1998, Petre Răileanu's Gherasim Luca, 2004, and Iulian Toma's Gherasim Luca ou l'intransigeante passion d'être, 2013. They include extensive bibliographies, though they tend to omit sources other than in French and Romanian. Two of Luca's key early works are currently available in translation: The Passive Vampire and The Inventor of Love; one later volume of poetry has also recently appeared in translation, Self-Shadowing Prey. (Variations in the spelling of the first part of Luca's name in these sources and the present text, with and without an accented ' $\mathrm{e}^{\text {', }}$ are explained by the fact that Luca himself only adopted the accented version after his move to Paris. Strictly speaking, "Gherasim Luca" should be considered as a compound surname with no given name.)

Space does not allow a more detailed reflection on Luca's complex relationship to Parisian surrealism after his relocation to Paris in 1952; a measure of the other circles Luca would orbit without joining comes from his presence in Fluxus events like the Festum Fluxorum, Paris December 1962, or the 1957 painting Bouquet made in collaboration with Beat poets Allen Ginsberg, Gregory Corso, and Peter Orlovsky, shown in the exhibition catalogue Ghérasim Luca, Cahiers de l'Abbaye Sainte-Croix (36).

Dada/Surrealism No. 20 (2015) 
If there are reasons for the silence around his writings from English-language scholarship, bound up above all with problems with text - the scarcity of many of his publications, the frequent near-impossibility of their translation - it is perhaps no surprise that another whole aspect of Luca's work, his visual experiments and their exchanges with written language, has similarly remained almost invisible; even in France, the country in which Luca's legacy is held in highest regard, this practice has received only limited critical attention and dissemination. The focus of what follows here is on just one, central part of this activity, spanning his life in Bucharest and Paris (the emphasis here is on the former): the invention of the cubomania (fig. 1). A collage in which source material is sliced into precise squares and reassembled as small grids of tessellated papers, its formal economy masks an ambitious conceptual framework that makes the process not only unique within surrealist collage practice but also one of the most theoretically-driven instances of surrealist image-making. Two exhibitions in Bucharest, in 1945 and 1946, and a pair of small publications - one, Les Orgies des quanta, devoted exclusively to the cubomania - presented the first results to the public. (Luca would return again to exhibiting his work in France from the mid-1950s onwards.) Identified as a key example of his theory of 'non-oedipal' relations, Luca located the cubomania at the intersection of the ideas of Marx and Breton, as a model for their critique of the alleged objectivity of social conditions and as exemplifying the violent rejection of the tyranny of oedipal forces over social and personal liberty ("Cubomanies"). Unacceptable as it is to separate one part of Luca's activity from the whole, to privilege the visual over the verbal - Luca's poetry represents one of the most distinctive engagements with the French language of the twentieth century - the cubomania seeks a place in the histories of surrealism's modes of seeing and making images. ${ }^{2}$

2 The cubomania has apparently never been examined in detail for English-language readers, just briefly described in translated sources such as Alexandrian (138), or Durozoi (448). In French, accounts are more widespread, but there are still seemingly only two texts entirely devoted to the subject: Benoît Decron's article "Cubomanies" is relatively brief, while Sibylle Orlandi's Master's thesis "Les Cubomanies de Ghérasim Luca: Dispositif sémiotique et métalangage visuel" deals at length with the cubomania, but currently remains less easily accessible. A concise, largely theoretical discussion is found in Carlat (113-17); a longer, more creative consideration of the cubomania in relation to Luca's written poetry is Serge Martin, "S'Asseoir sans Chaise avec les cubomanies et les ontophonies de Ghérasim Luca." For a contemporary surrealist response to the cubomania, this time introducing diagonal cuts to the grid, see Richard Waara, 'Metamorphosis of a Moorish Nude Postcard.' Two university dissertations by Aurélia Gibus ("Parcourir l'Impossible" and "Ghérasim Luca et les livres") help place Luca's writings in the context of his visual practice; an overview of Luca's visual work, containing an expanded discussion of the aspects outlined in the next section of the present article, are to be found in my own article, "La Poésie sans langue: Ghérasim Luca, Visual Poet." My profound thanks go to Micheline Catti for her support of my research in this field. 


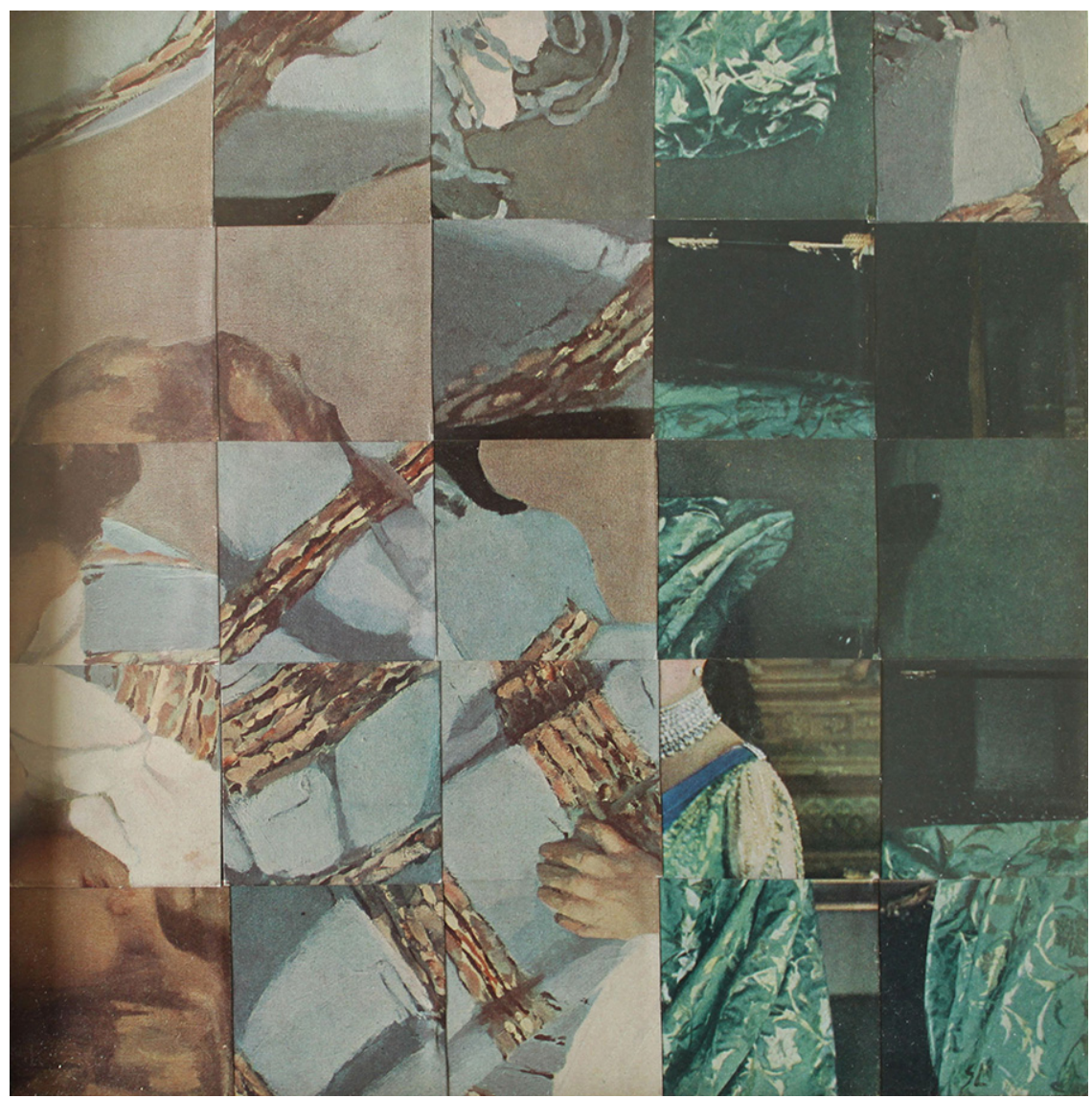

Figure 1: Gherasim Luca, untitled cubomania, 1945. Private Collection, Paris. (C) Micheline Catti-Ghérasim Luca.

"Il m'est toujours difficile de m'exprimer en langage visuel" 'It is always difficult for me to express myself in a visual language', Luca would claim (Bricianer, 32). Nevertheless, and no doubt unsurprisingly for a surrealist poet, the visual took a significant role in Luca's output, though it was an activity which despite his participation in a number of exhibitions in Bucharest and Paris seems to have remained a more confidential, less well-documented part of his work. On the one hand, his concern with the visual manifested itself in a heightened sensitivity to the appearance of his publications, where typography and presentation would be supervised with extreme care, while on the other manuscript writings such as letters (a privileged mode for Luca) featured playful use of careful handwritten scripts and were sometimes accompanied by collage 
elements and other graphic devices. ${ }^{3}$ Collaborations with artists were a notable aspect of Luca's activity from the 1950s onwards, and his books featured contributions and exchanges with figures such as Victor Brauner, Jacques Hérold, Matta, Max Ernst, Wifredo Lam, Jean Arp, Dorothea Tanning, and above all with his wife Micheline Catti. Sometimes this encounter could be sustained and complex, as with the intricate conceptual artworks made by Piotr Kowalski in resonance with the poet's writing, notably those exhibited at the Galerie Edouard Loeb in 1973 around Luca's book Le Chant de la carpe. Text printed on sheets of acetate, graphics based on the sound waves of Luca's voice, and sculptural works in which words met objects all pointed to the relationships between Luca's investigations into the secrets of language and the thresholds of the visual. ${ }^{4}$

During its brief lifespan in the 1940s the surrealist group in Bucharest, marooned in Central Europe and desperate for contact with other surrealists, had nevertheless expressed forthright critiques of what it saw as the international movement's recent slide from revolutionary fervor to a recuperable style and a set of repetitious techniques, particularly in the domain of art, including collage. (The Bucharest group's members were all predominantly writers, while the painters connected with them, Brauner and Hérold, spent this period in France.) The group would explore a range of explicitly anti-aesthetic (in Luca and Trost's words, "aplastiques, objectifs et entièrement non-artistiques" 'aplastic, objective and totally non-artistic' $)^{5}$ visual practices. Notable among these was the domain of the object, developed in particular by Luca during the early 1940s with his notion of the "Objectively Offered Object," a game in which found and constructed objects might act as lightning rods for interpersonal exchange, sorcery and divination; Luca's account of this experience Le Vampire passif is illustrated with a number of such assemblages. ${ }^{6}$ Other members of the group also developed distinctive visual forms, similarly all but lost to view today despite the burgeoning recent scholarship and curation of surrealist art. Paul Păun's delicate, wispy ink drawings pursued an automatism figured as ultra-fine meteorological phenomena or anatomical details. Trost, on the other hand, devised a formidable array of new automatic techniques, designed to uncouple visual production from the burdens

3 See for example facsimile letters in Morando and Patry (214-31), or letters reproduced from the Breton archives at $<\mathrm{http}: / /$ www.andrebreton.fr/fr/item/?GCOI=56600100453810>.

4 See Gibus, "Ghérasim Luca et les livres" for details of this and other collaborations between Luca and artist friends, as well as the section on collaborations in the present author's "La Poésie sans langue."

5 Luca and Trost, Dialectique de la dialectique (27). This key text is available in translation as "Dialectics of the Dialectic," though in an edited version that doesn't include all of the passages cited here.

6 See Fijalkowski, “The Objects of Gherasim Luca" and "La Poésie sans langue." Luca's work after the war would continue to be haunted by the theme of the object. 
of control and interpretation: mechanically-generated "pantography," "vaporizations" spreading ink with breath, "entopic graphomanias" joining the accidental blips on blank paper, "hypnagogic movements" featuring deliberately indecipherable shapes painted with eyes closed, or "echography" and "stereotypy" among other manifestations. ${ }^{7}$

Three exhibitions of such work indicated the group's desire to extend its public outcomes into the visual arena: one in January 1945 featuring Trost and Luca, followed by another featuring Paul Păun in February-March, and finally a third presented by the whole group in September-October 1946. This last event, Infranoir, was initially intended to be an international survey of surrealist art, an ambition frustrated by the precarious state of communications in Europe at that moment, and there is a sense in which the works on display, and the cubomania in particular, not only had to stand in for those from the absent international movement, but already to start the work of their inevitable critical dépassement. ${ }^{8}$ Significantly, the group's contribution to the 1947 International Surrealist Exhibition in Paris was not with artworks, but with a text proposing a great, pitchblack room in which to encounter unknown objects (Luca, Naum, Păun, Teodorescou, and Trost, "Le Sable nocturne"). After the war, however, Luca continued to pursue a number of visual experiments, such as fragile and meticulous drawings constructed from constellations of dots, and intriguing text/image dossiers in which found albums of photographs were re-energized by new poetic captions. ${ }^{9}$

\section{Cubomania, Collage, and Meaning}

One of the earliest and the most sustained of Luca's visual proposals, the idea of the cubomania appears to have begun in 1944. Refined over the next five decades, its essential principle remained the same: found printed source material photographs, engraved illustrations or reproductions of paintings (the latter predominant in the post-war works) - would be sliced into precise regular squares, at first typically between 4 and $6 \mathrm{~cm}^{2}$. Squares from these sources (usually just one per cubomania, sometimes more and then later from repeat copies of the same image) would then be re-assembled into small regular grid structures, initially square ones of $3 \times 3$ or $5 \times 5$ elements, then (in Les Orgies des quanta)

\footnotetext{
7 For a list of techniques, see Luca and Trost, Dialectique de la dialectique (27-28).

8 See the correspondence between Luca and Brauner charting attempts to include international artists in the 1946 show, in Morando and Patry (217-20). On the theoretical and philosophical positions of Infra-noir, see Eburne (with thanks here to Jonathan Eburne for allowing me to read an advance draft of this article).

9 See Fijalkowski, "La Poésie sans langue." The albums remain little known, despite their considerable interest.
} 
rectangles 3 units wide and 4 tall, and later still into more varied configurations. Sometimes each cubomania would be made from a single source image, sometimes more. From the 1960s onwards, cubomanias would often employ repeat copies of the same image, and they might be combined in sets of two, three, or four cubomanias and mounted on black-painted hardboard (known as Isorel) to form a single ensemble, in such a way as to set up a play between two and three dimensions. ${ }^{10}$ An example of an early work, Expérience d'un bâton carré au-dessus de

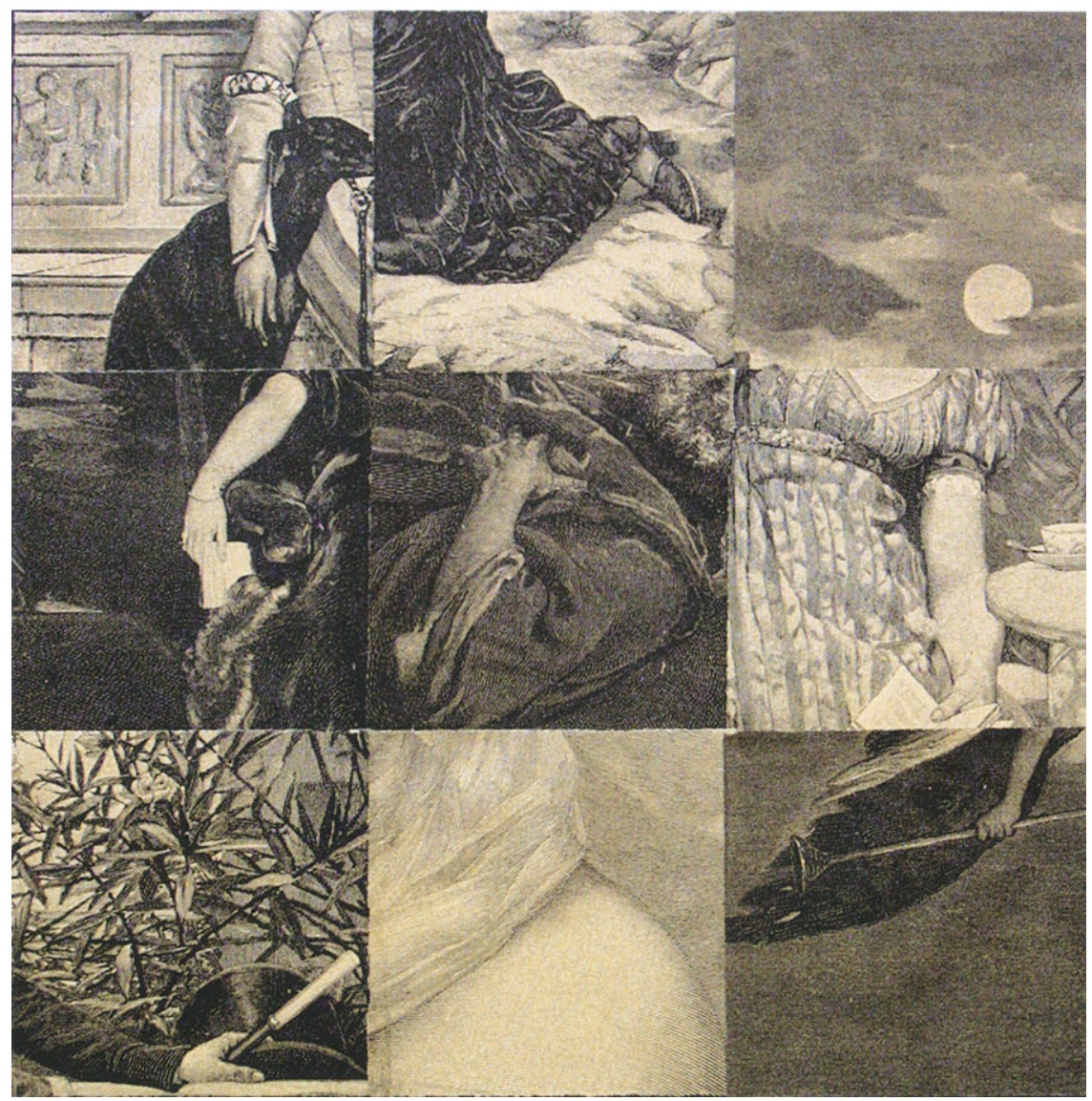

Figure 2: Gherasim Luca, Experiment With a Squared Stick Above Two Glasses, 1944. Private Collection, Paris. (C) Micheline Catti-Ghérasim Luca.

deux verres (Experiment with a Squared Stick Above Two Glasses) of 1944 (fig. 2), demonstrates at a glance the kinds of disorienting effects this can have on the

10 The fullest range of the cubomanias from across Luca's career can be viewed in the exhibition catalogue Ghérasim Luca, Cahiers de l'Abbaye Sainte-Croix. 
viewer. Images from a number of sources have been fragmented, and the resulting squares juxtaposed in ways that counteract or play with our inclination to make coherent sense of any given visual form. Deliberate blockages of continuity are set up both by placing unconnected squares beside one another (even if they might originate from different parts of the same original), and by the dizzy and apparently random orientation of each square, where some are presented 'right way up,' others rotated. While high and low, cultural and natural, interior and exterior, animal, vegetable, and mineral are gleefully jumbled, other tales take their place, rhyming body parts or finding unexpected chance echoes and continuations in adjacent squares to form a kind of hyper-condensed story in nine fragments.

We do not know the cubomania's precise origins, though as we shall see it bears both procedural affinities to and striking formal differences from previous surrealist collage practice, of which Max Ernst's collage novel series was perhaps the most exemplary during the 1930s, the last point at which Luca had direct access to French surrealism before the outbreak of war and his return from Paris to Bucharest. ${ }^{11}$ The early cubomanias sometimes adopted Ernst's use of outmoded source material, such as nineteenth century engraved book illustrations depicting bourgeois domestic melodrama or exotic adventures. But in contrast to the collage novels and to surrealist collage practice as a whole, the cubomania explicitly blocks any tendency to either narrative or visual coherence, however ambiguous, surprising, or uncanny these might be. In the cubomania, the world is not recast or reversed, stories not told anew. All is in motion, nothing falls into place to allow linear readings - rather, a mise en abyme of micro-readings forms and then peters out as the eye moves restlessly from one conjunction to the next, here a lucky correspondence between two squares or an echo formed from a doubling, there a sharp breach from one fragment to its neighbor. Where Ernst's own classic formula for the mechanics of collage - "the pairing of two realities which cannot be paired on a plane apparently not suited to them" (22) - emphasizes a tripartite structure of contradictory forms united against all the odds within a newly-energized context, the cubomania collapses difference both between images and between figure and ground. Since, unlike classic surrealist collage with its dissonant materials, it is not ordinarily possible to grasp the cubomania's distinct original components (indeed, its strategy is often to cut up and reassemble a single image), the sense is that difference and conflict are already present within each original; every representation contains the possibility of its own explosion. Dismembered image sources find their meanings and hierarchies dissolved, while the seamless joining of squares gives no quarter to incidental context or anecdote: "Le fragment

11 Decron (38) suggests that Luca temporarily interrupted making the cubomanias on his arrival back in Paris in the 1950s because they were too close to existing surrealist collage such as Ernst's. In other words, the cubomania would at first be somehow linked intrinsically to the contexts of Bucharest over those of Paris. 
et le tout," Luca specified, "se trouvent dans un rapport de contenu-contenant, mais uniquement dans le sens antithétique" ("Cubomanies" 281) 'The fragment and the whole find themselves in a relation of content-container, but only in the antithetical sense.' Distinctions between inside and outside, edge and center are set in play: everywhere is a border, everywhere is a rupture, and what should be "without" is now everywhere within. Finally, where collage such as Ernst's begins with a deft surgeon's snip, Luca's is a colder, mechanical and systematic process. Simple experiment will show that attaining the seamless matching of absolutely perfect squares is harder than it looks to achieve with a knife and rule, let alone scissors, and in fact Luca and Trost's account of their desire for "aplastic" works recommends the use of mechanized tools, a "machine à couper le papier" 'machine for cutting paper' in the case of the cubomanias. ${ }^{12}$

While the cubomania participates in surrealist collage's key strategies, identified by Elza Adamowicz as those of cutting, pasting, and creative détournement, the radical simplicity of its procedure, close to a pure process, means that it sits more problematically in her definition of the medium as "essentially a semiotic practice of transforming pre-formed iconic or verbal messages" (15-17). ${ }^{13}$ For Luca the grid of the cubomania works less along semiotic lines - those folds between things along which meaning is encoded and decoded - but cuts across them to throw the very possibility of such encoding and decoding into doubt. Since the cubomania's cuts are made not along outlines or boundaries, not according to distinctions between one form and another, but guided by an externally-imposed automatic logic, its real operation works less with the actions of seeing and distinguishing than on the very ontologies of perception and meaning themselves (in Luca's words, "le correspondant oculaire instantané de notre comportement vis-à-vis du monde extérieur" (277) 'the instantaneous ocular correspondence of our attitude towards the external world'). ${ }^{14}$ Reflecting on the structural interruptions of the image makes it tempting to see a close affinity between the cubomania's juddering pictures and the "stammering" and loosening

12 Luca and Trost, Dialectique de la dialectique (28). In English the name for this machine is explicitly loaded with revolutionary (not to mention anti-oedipal) overtones: a guillotine - a convergence Luca would surely have relished.

${ }_{13}$ Luca's cubomanias fall outside Adamowicz's focus on work from the inter-war period.

14 'Cubomanies' (n. pag.). It is perhaps for this reason that, superficially at least, the cubomania might be seen as bridging classic surrealist practice and the more conceptuallydriven critique of the image since the 1960s by artists such as John Baldessari. It's certainly the case that the cubomania - like several aspects of Luca's work - seems to anticipate quite different developments long after its inception; one would have to wait for the collages of figures like Jiří Kolář (himself emerging from a surrealist milieu in Prague) in the 1960s, or in Britain the more recent practice of John Stezaker, to find work that echoes some of its formal concerns. 
of language that characterized Luca's mature poetic style of the post-war period (a form first encountered in Luca's 1940s poem "Passionnément," with which an early cubomania shares a title); both seem to break their material down into its primary component parts. Tempting as it is to thus make the cubomania a form of precursor or testing ground for the later poetry, the parallel is perhaps a little too simple, diverting attention from what is distinctive between a textual and performative mode in which language seems to shudder and leap between latent meanings and verbal affinities, and a visual strategy in which the image blinks and comes undone. ${ }^{15}$ As an apparent departure from his writing, the rise of the cubomania nevertheless stalks Luca's contemporary publications: while his first major surrealist text Le Vampire passif features one on its cover, viewed from an angle and obscured by an object, a second key work from this period. Inventatorul iubirii (The Inventor of Love) was illustrated with five of them, underlining the play between poetry, collage and thought (fig. 3). ${ }^{16}$

With its imposition of an arbitrary but rigorous chance-dominated process on found printed sources, the cubomania might also be seen as inheriting aspects of Dada collage strategies, such as Arp's early works in which rough-cut squares are arranged "according to the laws of chance." In particular, it bears some comparison to a precedent with Romanian connections, Tristan Tzara's celebrated recipe for a Dada poem of 1920 recommending the "writer" to clip words from a newspaper and pull them at random from a bag before re-assembling them (39). ${ }^{17}$ While Tzara's status as a former member of the mid-1930s Parisian surrealist group who by the end of the decade had disavowed the movement would have

15 Martin (175), for example, argues that the two strands in Luca's work, cubomania and verbal play, are quite distinct; he also sees the cubomania as unrelated to games or to mainstream collage practice (relationships the present article examines below).

16 Luca, Le Vampire passif (1945, reprinted 2001 and translated as The Passive Vampire, 2008); Luca, Inventatorul iubirii. Cubomanias featured in Luca's post war publications as well, for example in a giant-format boxed portfolio Crier taire sourire fou featuring short texts by Luca interspersed with Gilles Ehrmann's photographs of Luca's cubomanias, glued to the pages in a variety of sizes and configurations and underlining the possibility that cubomania and poetry might share the same environment. Intended as a prototype for a larger edition, only two copies were made, one of which is apparently lost.

17 This connection is made, for example, by Răileanu (140). Another, more tentative, source with Romanian connections - not that Luca would have cared for enquiries along such nationalist lines - is a photographic album by Benjamin Fondane from the 1930s, in which either rational or arbitrary selections of images are arranged in loose, playful grids on black backgrounds. The album has only recently become known through its inclusion in the exhibition and catalogue La Subversion des images (Bajac 206-07), but it seems plausible that, as fellow expatriates and friends of Victor Brauner, Fondane and Luca may have discussed the work during the latter's stay in Paris at the end of the 1930s. 


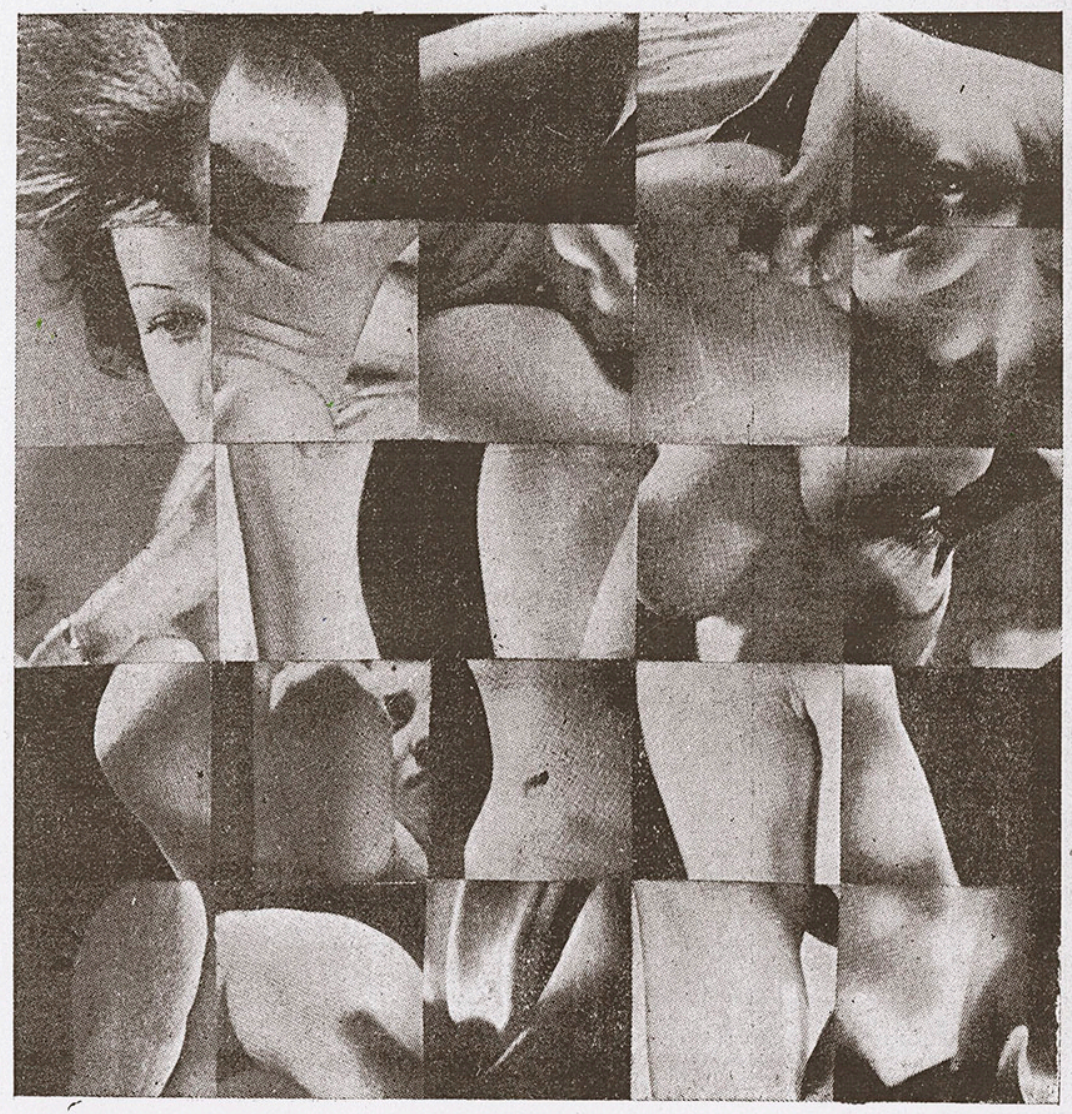

Figure 3: Gherasim Luca, untitled cubomania, from Inventatorul iubirii, Bucharest 1945. Private Collection, Paris. (C) Micheline Catti-Ghérasim Luca.

made this link to Tzara less attractive for Luca, ${ }^{18}$ it might also be argued that Tzara's emphasis on an ironic or sarcastic Dada procedure, reducing meaning to random utterance, seems quite distinct from what, as we shall see, Luca was proposing as a purposefully critical and dialectical practice. The relevant question here, nevertheless, concerns the degree to which chance and automatism were invited to play a role in the making of each cubomania. At least one part of the process, the mechanical cutting up of source images, takes much choice and

18 Luca and his surrealist comrades would send Tzara an insulting letter during the latter's visit to Bucharest in November 1946 (letter to Brauner November 1946, in Morando and Patry, 243). 
control out of the maker's hands, but the next stage - selecting and then assembling the resulting squares - involves greater intervention. A simple experiment in photocopying and re-fragmenting the squares of cubomanias from, for example, the series in Les Orgies des quanta (fig. 4), suggests that only a small proportion of each source image has survived the process: having sliced up the original(s), Luca has retained only a fraction of the first whole, and the originals could no longer be reconstituted from the cubomania's components. In the selection and organization of the resulting squares one's instinct is that, as with many surrealist texts and drawings purportedly invoking Breton's notion of pure psychic automatism, the works were likely to have been the result of a dialogue between hazard and deliberation, drawing on the playful tensions between lucky accident and careful editing, pitching logics of interpretation against the secret but insistent internal economies of the source material.

As relevant as any artistic or literary precedent, however, is the form of children's nursery puzzle developed in the early nineteenth century and familiar to any European child of the early twentieth century (and still occasionally found today) of small but robust wooden picture blocks whose square sides bear the divided-up elements of six different images. In principle itself a collage format, since to make the cubes pre-printed pictures are cut up and glued to the wood, the puzzle is solved by turning and rearranging the blocks to rediscover each complete image in turn. Anyone who recalls playing with such a toy will no doubt have shared the pleasure not only of making each element rotate satisfyingly into place, but also of playing with deliberately wrongly oriented or misaligned blocks so as to disrupt the logic of the 'correct' images. ${ }^{19}$ Such games are a variant on the large range of traditional children's games and puzzles involving the movement and manipulation of wooden cubes (the word 'cube' comes from the Greek kybos meaning a die), from alphabet and construction toys or Polish klocki to ancient Chinese and Japanese wooden text puzzles, all of which combine simple manipulations that are also invitations to young children to assemble, reassemble and above all joyfully demolish the literal and metaphorical building blocks of their world. Perhaps it is for this reason, along with the tempting connection to the privileged realm of childhood (appealed to repeatedly by surrealism though not otherwise one of Luca's particular concerns), that the term 'cubomania' should

19 These puzzles are often evoked (though to my knowledge never directly used) by Joseph Cornell, who on several occasions included printed images mounted on blocks in his assemblages; they do however feature in the work of Czech surrealist film-maker Jan Švankmajer, in his homage to Lewis Carroll Jabberwocky of 1971, where they appear as a recurrent signal of the carnivalesque reconfiguration of the child's nursery world. Play, as theorised by Johan Huizinga in Homo Ludens (written in 1938, and thus roughly contemporary with the cubomania), owes its character to the paradoxical generative principle of freedom within structure, of newly-minted logic that breaks with all existing logic and acts as its mirror, its other, and as the space within which change is tested and perfected. 


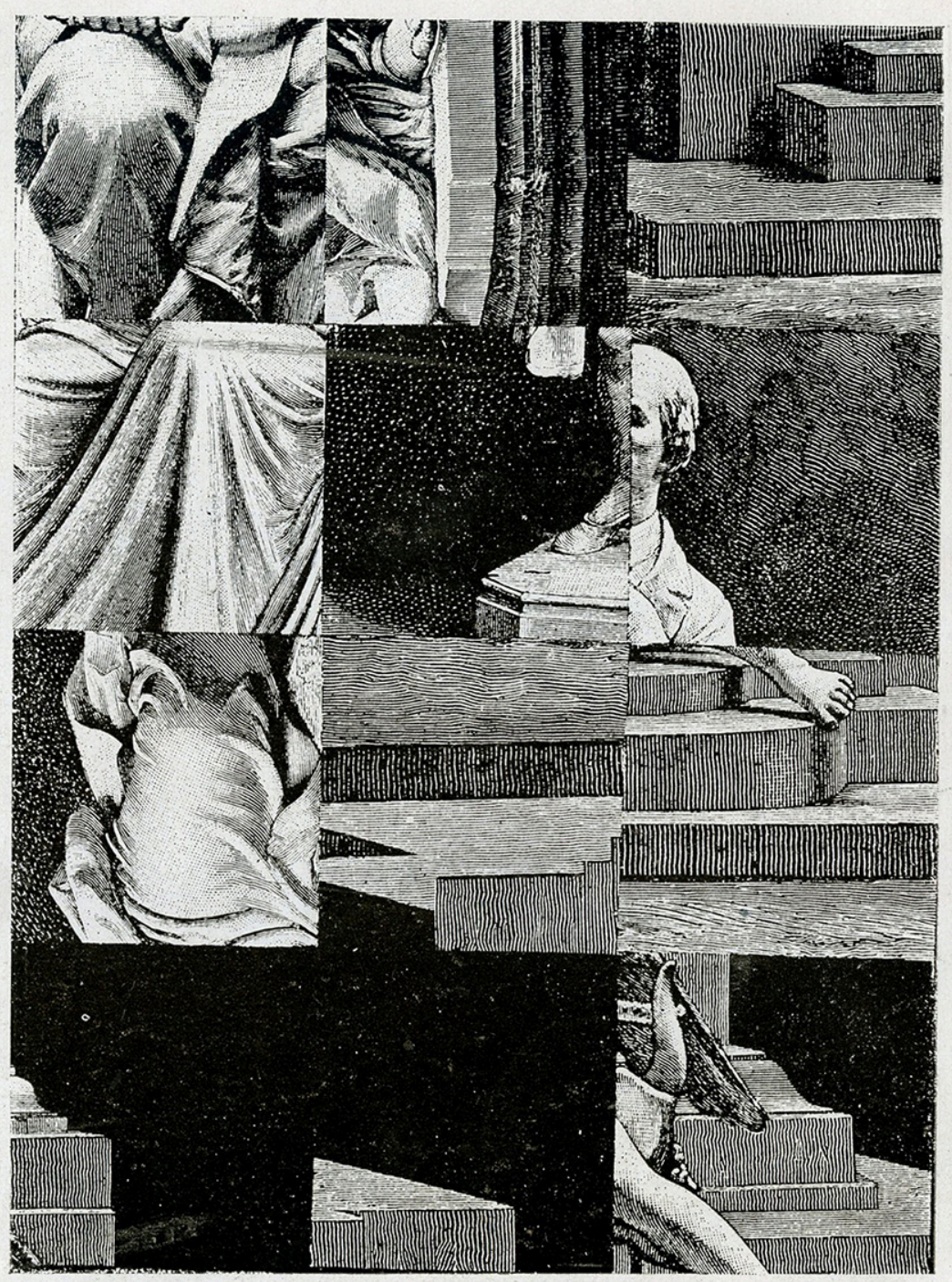

Doubler le réel

Figure 4: Gherasim Luca, Double the Real, from Les Orgies des quanta, Bucharest 1946. Private Collection, Paris. (C) Micheline Catti-Ghérasim Luca.

have been chosen for a plainly two-dimensional collage practice, one whose logic Luca nevertheless proposed extending past the image and into the world beyond 
it, its name emphasizing a potential for dynamic three-dimensionality against the stasis of flat pictures.

\section{The Cubomania and Non-Oedipal Play}

Solemn and ribald, combining the gravitas of a ceremony with the pleasure of disinterested play, for all its modest format Luca saw the cubomania as part of a sweeping attack on the perception of the world, following the dialectical logic of the negation of negation. The text of the slim catalogue Luca and Trost published on the occasion of their 1945 exhibition Présentation de graphies colorées, de cubomanies et d'objets, and which contained Luca's main theoretical statement on the cubomania, opened with this joint declaration:

Nous sommes d'accord avec le rêve, la folie, l'amour et la révolution.

Nous rejetons sous tous leurs aspects l'art, la nature, l'utilité, la séparation de la société en classes, la loi de gravitation, l'idéalisme, la thérapeutique, la peinture, la séparation entre le rêve et la vie, la psychologie, la magie blanche, la misère, la mémoire, les restes diurnes dans le fonctionnement onirique, la géométrie euclidienne, les chiffres défavorables et la mort.

Nous sommes d'accord avec les inventions délirantes, les larmes, le somnambulisme, le fonctionnement réel de la pensée, l'élixir de longue vie, la transformation de la quantité en qualité, le concret, l'absurde, la négation de la négation, le désir, l'hystérie, les fourrures, la magie noire, le délire d'interprétation, la dialectique de la dialectique, la quatrième dimension, le simulacre, les flammes, le vice, le hasard objectif, les manies, le mystère, l'humour noir, la cryptesthésie, le matérialisme scientifique et les taches de sang. (271)

We agree with dream, madness, love, and revolution.

We reject in all their aspects art, nature, utility, the class division of society, the law of gravitation, idealism, the therapeutic, painting, the separation between dream and life, psychology, white magic, poverty, memory, diurnal remnants in oneiric functions, Euclidean geometry, unfavorable numbers, and death.

We agree with delirious inventions, tears, somnambulism, the real functioning of thought, the elixir of long life, the transformation of quantity into quality, the concrete, the absurd, the negation of negation, desire, hysteria, furs, black magic, the delirium of interpretation, the dialectics of the dialectic, the fourth dimension, the simulacra, flames, vice, objective chance, manias, mystery, black humor, cryptaesthesia, scientific materialism, and bloodstains. 
This characteristically manic list of the Romanian surrealist articles of association, lurching from one extreme to another, from grand themes to specific objects, would be unpacked with more care in Luca and Trost's key "manifesto" of later that same year (some of whose claims the reminder of the group in fact rejected), Dialectique de la dialectique. Passages in both documents specify that their visual works, far from constituting an artistic practice of the kind that Dialectique de la dialectique critiqued, should be read as the visible signs of a revolutionary theoretical program. Titles of the cubomanias exhibited in 1945 (presented as unbroken paragraphs interspersing Luca's text, rather than as a separate itemized list), many of them apparently "readymade" names from other sources, often suggest reading the works as scientific or ethical propositions: Expérience sur la chute des corps (Experiment with the Falling of Bodies); Tenter l'impossible (To Attempt the Impossible); L'Analyse des hasards et le jeu de la vérité (The Analysis of Chance and the Game of Truth.) Less an illustration of such theoretical intentions than their physical evidence, the cubomania would come to exemplify three of the major conceptual themes of Luca's writing of the coming years: negation, eros, and revolution.

If the cubomania was first developed around 1944, its initiation coincides with the end of the pro-fascist wartime Romanian regime in late August of that year, a transition unlikely to have been experienced as a straightforward liberation since the war itself was far from over. Born into destruction and demoralization, during a period of catastrophe in which Luca had been made to carry out forced labor as a street cleaner and labor camp worker, and obliged to clear away rubble and bodies after enemy bombardments (Manucu 14), it is little wonder that the cubomania operates under the sign of negation in its systematic violence against the image. A major earthquake in November 1940, causing considerable destruction in Bucharest and described in The Passive Vampire, had heralded an era of collapse and affray the cubomania seems to share, and indeed Luca's recipe for extending the cubomania's logic in a "leçon pratique de cubomanie dans la vie courante" ("Cubomanies" 281) 'practical lesson in everyday life' included the recommendation to break buildings into pieces; cited among its equivalents in architecture is "une rue pendant un tremblement de terre" (281) 'a street during an earthquake.'

Described as "une vraie fossilisation de notre époque" (281) ‘a true fossilization of our epoch,' what seems at first sight to be the cubomania's tightly-stacked construction starts in this light to resemble instead the knitting together of broken remnants of an era whose demise Luca was glad to celebrate, the chaotic geology of a disintegrating world of images, whether these have been deliberately demolished or were simply no longer tenable; as Luca would write around this time, "Totul trebuie reinventat, nu mai există nimic pe [sic] toată lumea" (Inventatorul iubirii 231) 'everything must be reinvented, nothing exists anymore 
in the whole world' (Inventor of Love 18). ${ }^{20}$ Late nineteenth century engravings, reproductions of early twentieth century academic or impressionist-style paintings, and contemporary mass-media photographs of nudes, the three sources of the cubomanias of the 1940s, together span an era of the previous fifty years whose structural integrity had failed (Luca's project echoing in more violent and pessimistic form Walter Benjamin's archaeology of the outmoded fragment or ruin). A permanent revolutionary state, Luca and Trost would write, "ne peut être maintenu et développé que par une position dialectique de permanente négation et de négation de la négation, position qui puisse prendre toujours la plus grande extension concevable, envers tout et envers tous." (Dialectique 14, authors' emphasis) 'can only be maintained and developed through a dialectical position of permanent negation and of negation of negation, a position that might always take on its greatest possible extension, towards everything and everyone.' "La cubomanie nie. La cubomanie rend le connu méconnaissable" ("Cubomanies" 281) 'The cubomania denies. The cubomania renders the known unknown,' Luca affirmed. In fragmenting this already ruined immediate past, the cubomania acts to reverse and deny its ideologies, to negate its negations, and perhaps in so doing to reveal its pathological unconscious structures.

At an immediate level, of course, the cubomania operates solely with visual representations (even if Luca explicitly saw its destructive impetus as having the potential to spread into the world beyond), working on what Dialectique de la dialectique called "le problème de la connaissance par l'image" (26) 'the problem of knowledge through the image.' Luca and Trost's writings of the period repeatedly confronted the image's supposed objectivity, challenging the legitimacy of the status of the artwork and often proposing visual forms that deliberately ignored or blocked the possibility of their interpretation (even when they extended surrealist automatic procedures that hitherto had invited readings along symbolic or psychoanalytic lines). Trost's techniques proclaimed the "mystère des traces est complet et on ne peut, d'aucune manière, les introduire dans une image connue" (274) 'complete mystery' of their mark-making that 'cannot, in any way, be inserted into a known language', emphasizing both their situation at the limits of unconscious processes and their denial of current conceptualizations of the image: what remained artistic instead, Trost argued, was "l'opération nécessaire à leur production même" (272) 'the operation needed for their very production.' Trost's book Le Profil navigable distinguished between artistic means of production and what he saw as the strict application of scientific processes materializing the unknown all around us (Luca and Trost, Dialectique 26).

Acting as a negation of the world's oppressive images, the resulting works also functioned as implicit critiques of what Dialectique de la dialectique had stigmatized

20 "Chercher le triple sur les ruines du double" (296) 'Seek the triple on the ruins of the double,' the collective text for the Infra-noir exhibition had commanded (Luca, Naum, Păun, Teodorescou, Trost, L'Infra-noir 296). 
as surrealism's own "artistic deviations." In its dismantling of its image sources, at one level the cubomania is also a dialectical undoing and dépassement of the surrealist image, the wrecking of any sustained possibility of image-making in a world pledged to collapse. This might echo the relationship between Luca's writings and other existing works, notably surrealist texts by Breton: Dominique Carlat sees Luca using previous books "considérés non comme une source, mais comme une incitation à leur propre dépassement: les critères ne seront plus de fidélité ou de soumission à une autorité, mais de recomposition, refiguration et de sensibilité à une séduction" (131; italics Carlat's) 'considered not as a source, but as an incitation to their own dépassement: the criteria will no longer be those of fidelity or of submission to an authority, but of recomposition, refiguration, and of sensibility to a seduction.' The cubomania might be read as operating a parallel recomposition and refiguration not only on its found raw materials (except that these pieces of paper might precisely be less a means than ends in themselves whose destinies have been redirected), but at the same time, by choosing the type of images hitherto appropriated by surrealist artists such as Ernst, on the very practice of collage itself.

Can this destructive drive also be read as the necessary prelude to a constructive or regenerative impulse? The cubomania, after all, builds from what it takes apart, discovers in its ordered geometry a kind of rigor from chaos; this is, perhaps, the dismemberment not of the murderer but the pathologist, cutting and opening to understand rather than to destroy. ${ }^{21}$ A sense of this tension between dissolution and rebuilding can be seen, for instance, in the sequence presented in Les Orgies des quanta of 1946, whose cubomanias often alternate between the unravelling of textiles or drapery and the reorganization of architectural fragments, with the female body often presiding over both impulses (fig. 5). Yet even as the product of the negation of negation, conjuring dialectical movement from a double denial, Luca's writings of the 1940s revolve around a shattering that takes consciousness beyond such oppositions. One way through this troubling ambivalence might lie in the very form of the cubomania, prominent from the moment of its inception, namely its structure as a grid. An emblematic modernist form, according to Rosalind Krauss, the grid embodies modern art's claims for silence against narrative, bringing together the material and the universal, and above all elevating its ideas to the level of myth, that structure designed precisely to suspend opposing things together (9-13). In Krauss's words, "antinatural, antimimetic, antireal" (9), her reading of the modernist grid seems to offer something resonant with the cubomania's contradictory and conceptual nature even as Luca explicitly seeks to deny its artistic status, and even if surrealist production as a whole is noticeably absent from or runs counter to Krauss's

${ }^{21}$ For a discussion of collage manipulation as surgical autopsy rather than destruction in the context of the work of Jiř́ Kolář, see Pohribny (10-11). 


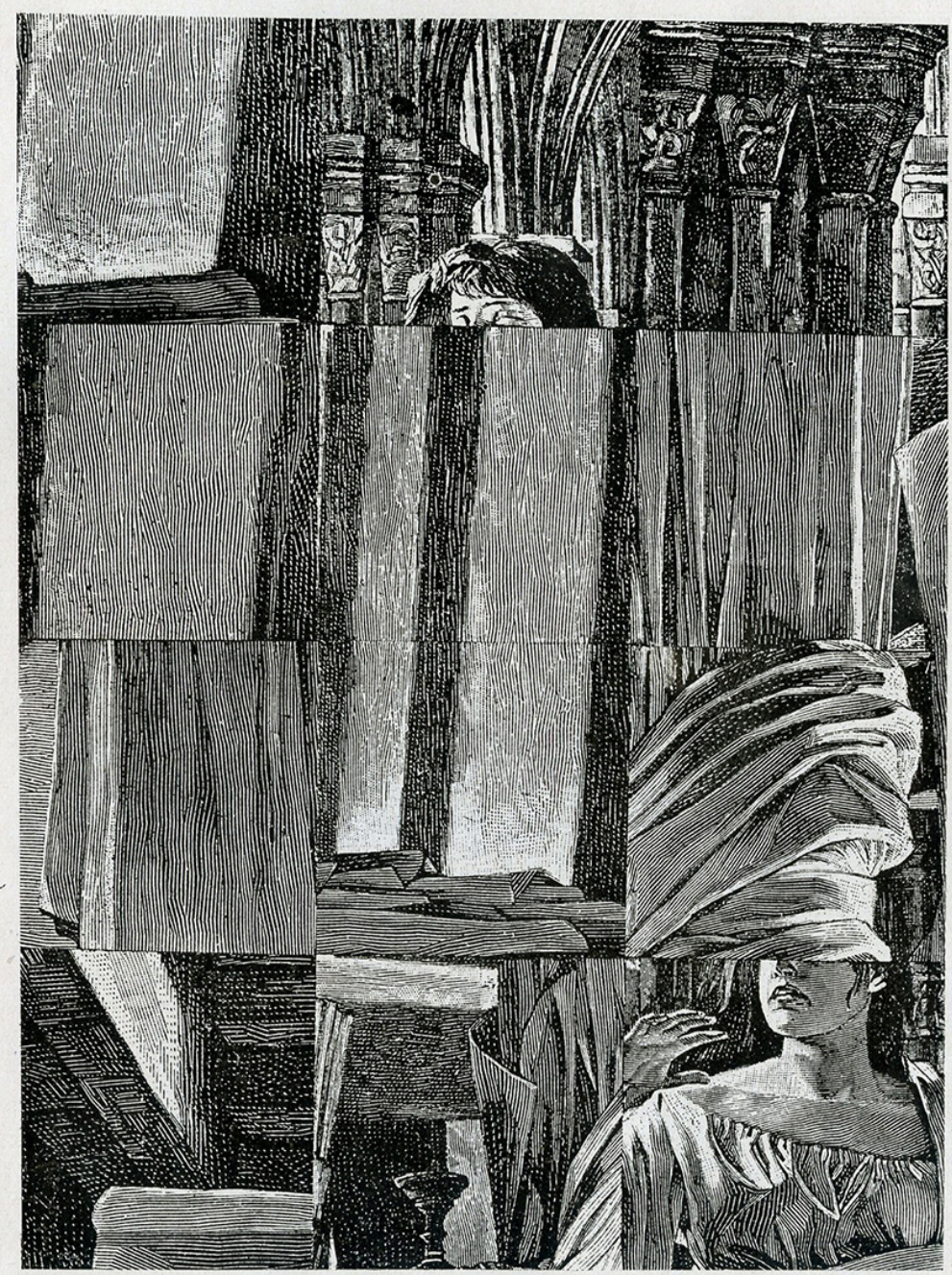

Indéterminisme d'un amour

Figure 5: Gherasim Luca, Indeterminism of a Love, from Les Orgies des quanta, Bucharest 1946. Private Collection, Paris. @ Micheline Catti-Ghérasim Luca.

narrative (as one might expect from surrealism's problematic relationships to modernism and the avant-garde). ${ }^{22}$ The notion of the grid as organizational play,

22 Krauss's article is accompanied by an image of a box assemblage by Cornell, an artist not otherwise referred to in her text. Surrealist grids are relatively rare, but they can be found: 
as schizophrenic window, might hold some sway for the cubomania and the repetitive or serial nature of its practice - an echo of the possibility of the work as chessboard (a form identified in particular with Marcel Duchamp and Man Ray), in which black and white represent a necessary, endless dialogue between logic and the imaginary, strategy and chance. But the cubomania, of course, has no interest in the kind of formal games the grid represents for modernist art, seeking to pulverize as well as to stack together, driven not so much by an organizing principle as the end of all principles.

The image sources of the cubomanias may vary, but one theme uniting them is the body: with very few exceptions, every example features elements of the human figure. Sometimes the corporeal presence is quite explicit; sometimes, especially in the later collages, just a small body part, a hand, limb, or slice of face, peeps from among drapery or objects, forming gestures rehearsed and repeated in a catalogue of covert fetishized rituals. In most, though not all, cases this is a female body (the cubomanias illustrating Inventatorul iubirii, for example, were made from photographs of nudes - fig. 3), and as such these are works which might be subjected to the familiar analyses and critiques of the surrealist representation of female anatomy and identity found elsewhere. The fact that these are critical, dialectical operations on images - especially on other people's artworks - makes it plausible to argue that the first target of the cubomania is not the flesh but representation itself. But these are also passionate engagements, as anyone aware of the role of eroticism in Luca's writings would suspect.

One of the earliest cubomanias, Passionnément of 1944 (fig. 6), submits apparently innocuous photography and painting to polymorphous desire. In the top left corner, two recognizably female faces kiss and merge - in fact, this is the same face bisected, the two parts both the same yet strangely foreign to each other by the operation of separating and mirroring their halves. The experiment of refragmenting a photocopy of the work and attempting re-assemble its original sources (fig. 7), helped by the fact that seeing the original collage itself gives clues to their reconstruction by observing the aging of different papers, reveals that not all of the elements are of perfectly equal size. Most squares seem to come from proximate sections of their respective source, and each source tends to contribute

particularly relevant here, perhaps, are Brauner's satirical body morphologies of 1933-1934, but also Magritte's word-image lessons from the late 1920s onwards, Dali's photomontage The Phenomenon of Ecstasy (1933), or the montages of surrealists' faces around Germaine Berton or Magritte's La Femme cachée of 1929 in the pages of surrealist journals. Perhaps closest in form to Luca's cubomania, superficially at least, is Man Ray's Surrealist Chessboard of 1934, in which once again photographs of surrealist group members are arranged in a tight grid structure. These and other surrealist photographic grid structures are to be found for instance in the exhibition catalogue La Subversion des images (Bajac et al., for example 43-49 and 196-207, with a cubomania p.199). But all of these tend to use the grid as comparison, juxtaposition or array, often in imitation of sources such as popular science journals, rather than to fragment the image from within. 


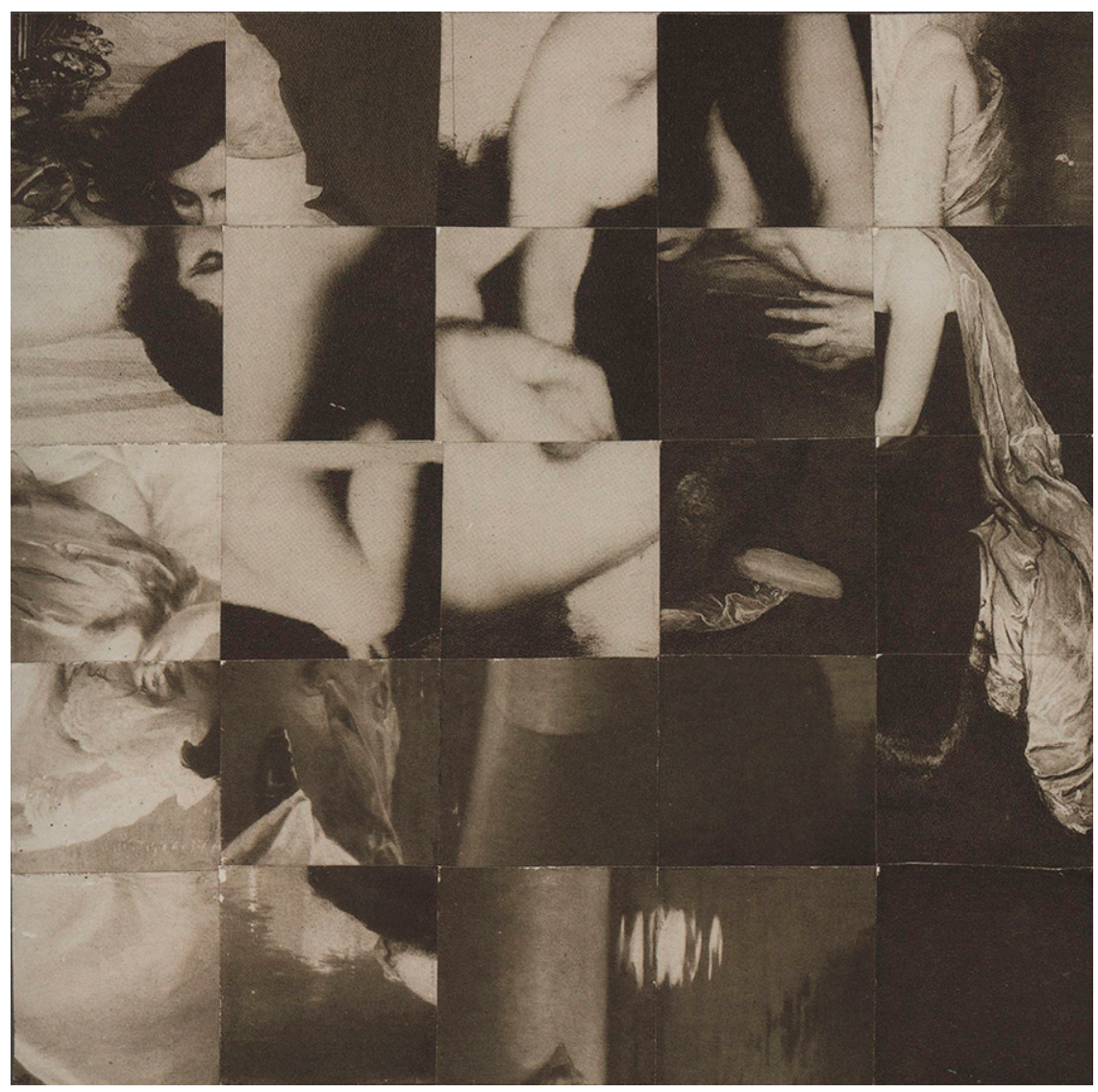

Figure 6: Gherasim Luca, Passionnément, 1944. Private collection, Paris.

(C) Micheline Catti-Ghérasim Luca.

a distinct zone of the final cubomania rather than being scattered across the grid. Passionnément derives from at least four different images, featuring nude and clothed female figures, some of them photographic (an image of a supine woman with her eyes closed), others apparently coming from monochrome reproductions of paintings. All the source images feature heavily contrasting highlights and deep shadows; drapery and a suggestion of water seem to link several of them as well. None of them, one notes, are "explicit" images, yet once fragmented, reoriented, and scattered, the results are both disorienting and subtly sexualized. As the eye roves across the game board of the work, limbs and hands emerge from corporeal darkness to touch or penetrate each other, caresses meet cloth resembling 
Dada/Surrealism No. 20 (2015)

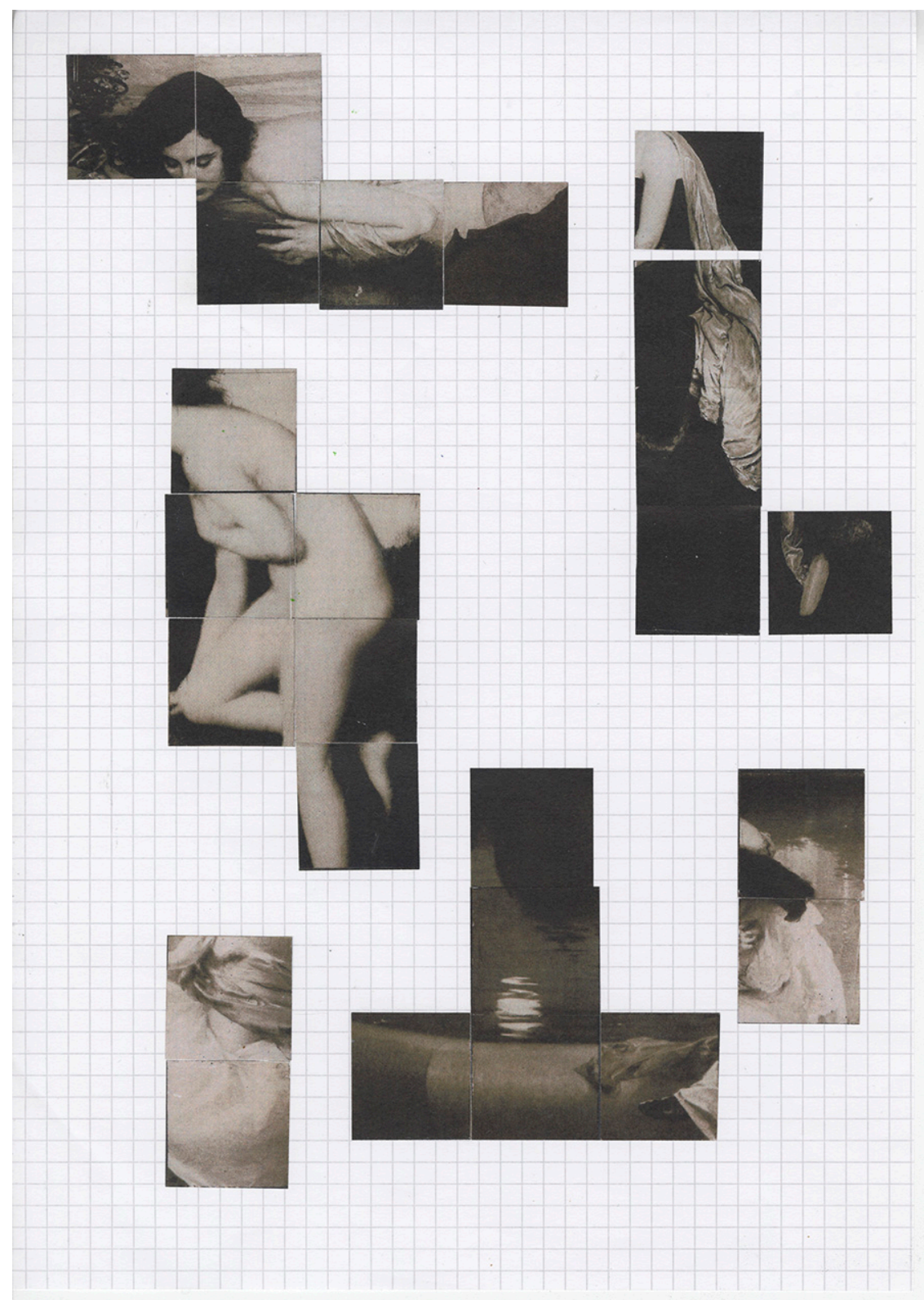

Figure 7: Reconfigured elements of Gherasim Luca, Passionnément, 1944. 
ectoplasm, nocturnal shades crowd in on what we read as bedclothes. No shape quite makes sense or has time to prolong its erotic trajectory before the next profanity takes over. ${ }^{23}$

While erotic love has a sovereign value throughout surrealism, the Bucharest group, and Luca's work in particular, give it a particularly distinctive expression. Dialectique de la dialectique designated 'objective love' as the "méthode générale révolutionnaire propre au surréalisme" (17) 'general revolutionary method appropriate for surrealism,' a concrete means of knowledge and action drawing on the thought of de Sade, Engels, Freud, and Breton. Its authors called for the eroticization of the proletariat, emphasizing what Luca and Trost cite as a movement embracing and going beyond the "psychopathologie de l'amour" (17) 'psychopathology of love' to harness its destructive power. This aggressive erotic psychopathology is inscribed in the cubomania too. Its equivalents in love, Luca would write in his Presentation catalogue text, are "les images pensées, dirigées vers la bien-aimée, dans les longues rêveries passionnelles. Dans la sexualité: le fétichisme, le sadisme, la myxoscopie, l'anthropophagie, les attouchements dans l'obscurité." (281) 'thought images directed towards the loved one during long passionate reveries'; those in sexuality are 'fetishism, sadism, myxoscopy, anthropophagy and touching in the dark,' and five "cubomanies non-oedipiennes spécialement érotiques” (282) 'especially erotic non-oedipal cubomanias' are listed on the following page. The cubomania stands, as Luca would write to Brauner in June 1946, as an attempt to rescue desire from the clutches of an oedipal past, to reclaim

l'image tentante de cet objet à aimer qui cesse, enfin, d'être un objet tout fait . . . pour devenir le perpétuel aphrodisiaque d'un objet à refaire, à tout faire, où la femme-aimée prend toujours le visage merveilleusement mobile du lendemain. La cubomanie n'est qu'une démonstration par l'image de mon comportement courant vis-à-vis de la femme-aimée. (Morando and Patry 220-21)

the tempting image of this love object which is at last no longer a readymade object ... to become the perpetual aphrodisiac of an object to make, to remake, to do anything, in which the beloved forever assumes the marvelously mobile face of tomorrow. The cubomania is nothing but a

\footnotetext{
${ }^{23}$ It is tempting to open a parenthesis here on a reading of the erotic cubomania in terms of Gilles Deleuze and Félix Guattari's Anti-CEdipe, as representations of deterritorialized desire. The echoes between Luca's non-oedipal thought and the work of Deleuze and Guattari remain to be explored; Deleuze, while aware of Luca's post-war poetry (cited in Anti-CEdipe and the television interviews Abécédaire), and indeed hailing it elsewhere in the highest terms, makes no direct public mention of this startling precedent, though correspondence (73) reveal he was aware of Luca's theory, and the appendix to Anti-CEdipe (271-72) notes Luca and Trost's Bucharest writings without quite crediting Luca with precedence.
} 
demonstration through the image of my current attitude towards the beloved.

A letter to Hérold five years later outlining Luca's long-term project for 'the objectification of love' is even more radical: "Ma femme a été pendant plusieurs années une sorte de 'cubomanie' vivante faite de plusieurs corps de femme (irréductible à l'image maternelle, charnellement et passionnément aimée dans son unité transfigurée-transfigurante)" (Letter to Jacques Hérold 62) 'For several years my woman has been a kind of living 'cubomania' made up of several women's bodies (irreducible to the maternal image, carnally and passionately loved in its transfigured unity: transfigured-transfiguring).'

Luca's texts of the early 1940s orbit obsessively around a vision of erotic love as an all-consuming paroxysm, in which every perversion is justified and invoked. The book in which this is perhaps most vividly explored, as the first part of a dialectic that navigates the constellation of eros, death, and revolution, is Inventatorul iubirii. Illustrated with cubomanias in its original Romanian edition, the notion of love as a ruining and dismembering, where image and flesh alike are put to the knife so as to reorient the whole world's relations through the transfiguration of the lover, is expressed here with extreme urgency. Like the cubomania, a form with no gaps or pauses, it is as though each sentence of this vision never wants to end:

Îndrăgostit de această iubită numai după ce am refuzat condiția axiomatică a existenței, denunțându-i pe autorii zilelor mele în măsura în care l-am ucis pe Creator, îmi permit libertatea de a nu iubi o imagine gata făcută de Creator și de a urmări apariția pe lume a acestei iubite așa cum aş privi stupefiat desprinderea din haos a unei planete depărtate, de a asista la atracția și la repulsia pe care o exercită între ele diferitele părți ale corpului ei mereu surprinzător, la risipirea, la cristalizarea, la răcirea și arderea simultană a acestei nebuloase adorate care e iubita mea într-o continuă devenire, într-o sublimă negare a întregii ei făpturi mereu inventate, trezindu-mă în fiece dimineață cu o altă imagine a iubirii pentru că în această iubită mereu inventată se întâlnesc toate acele fragmente vii găsite pe ruinele biologice ale umanității dispărute, fragmente de corpuri, de aspirații, de fosile ale iubirii iar nu un corp întreg de femeie în care stau închise la un loc într-o dezolantă promiscuitate micile ei virtuți dublate de mici vicii, caldul și recele ei, necazurile și exaltările ei, lacrimile și bucuriile. (238)

Enamored of this lover only after I have refused the axiomatic condition of existence, denouncing the authors of my time in the same manner that I have murdered my Creator, I permit myself the freedom of not loving an image already made by the Creator and of witnessing the appearance in this world of this lover in the same way that I would witness in astonishment the disengagement of a distant planet from chaos, of 
participating in the attraction and repulsion played out between different parts of her ever-surprising anatomy, in the dissipating, the crystallizing, the simultaneous burning and cooling of this adored nebula, which is my lover in a perennial state of becoming, in a sublime negation of her entire being, perennially invented, waking up each morning with a new image of being enraptured, because inside this lover you can find all those live fragments found in the biological ruins of long-vanished humanity, fragments of bodies, of aspirations, of love's fossils, but not a complete body where her little virtues doubled by her little vices are locked in one single place in desolate promiscuity, the warm and the cold, her sorrows and exaltations, her tears and joys. ${ }^{24}$

Both the evocation of perversions, often stressing their clinical vocabulary, and the intensity of expression in such texts point to the sense that this evocation of erotic transformation is a psychological as much as physical experience. Like many of Luca's texts of this period the cubomania - its very name suggestive less of an artistic practice than of a clinical condition, less an object than a state - stresses a compulsive repetition and manic operation, reminiscent of the repetitive and obsessive stuttering of many of Luca's subsequent poetic texts. The echoing and uncanny doubling of many of the cubomanias figures here as a willed summoning of repressed desires, as though this collage form were part magic ritual, part psychiatric case-study, a blend of sorcery and science characteristic of Luca's writings of the period such as The Passive Vampire and The Inventor of Love.

The latter book, seen by Luca as a key expression of non-oedipal theory, is invoked explicitly by him in the context of the cubomania's will to liberation: "le mouvement perpétuel, le désir de désirer, la négation de la négation et la superbe nécessité surdéterminante d'inventer notre destin" (“Cubomanies" 278) 'perpetual movement, the desire to desire, the negation of negation and the superb over-determining necessity for the invention of our destiny.' In its widest sense, then, the cubomania, in its ruining and destructive strategies, in its enactment of a violent (Sadeian) eroticism, is to be read as a political act. If the cutting of collage might at one level always be seen as an implicitly political intervention, the cubomania's systematic operation is not merely a cut in retaliation against castrating Oedipus, but a slicing first to ribbons, then to little pieces. As Luca and Trost's Dialectique de la dialectique had made clear, surrealism's claim over 'objective love' is to be seen as a material, revolutionary engagement, subjecting love and eroticism themselves to a dialectical process capable of acting on the laws of nature and culture alike, with the aim of overthrowing their oppressive,

${ }^{24}$ Luca, The Inventor of Love (28), translated from the original Romanian edition of 1945 (and my thanks to Julian Semilian for his valuable help in supplying the original text). The later French edition of 1994, revised by Luca himself, had broken this prose up into poetic stanzas, and omitted its illustrations of cubomanias and objects. Subsequent translations into other languages likewise lack these images. 
castrating logic through its non-oedipal position. The authors assert that "toute révolution de classe doit être doublée concrètement d'une révolution contre la nature" (Dialectique 20) 'Any class revolution must be concretely doubled by a revolution against nature.' Modest as it might appear as a tangible first step, the cubomania functions as a manifestation of this will to revolution that could operate simultaneously as a violent dismantling of cultural values - the conventions of representation - and apparent biological truths - the ordering of nature, structure, and the body.

Both the opening manifesto of Luca and Trost's exhibition catalogue and Dialectique de la dialectique would orient this critical attitude towards the very laws of nature in terms of an annexation of recently emerging scientific knowledge. Non-Euclidean geometry, non-Pasteurian biology, the fourth dimension, Brownian motion, quanta and space-time are all cited (albeit without explanation or contextualization) in an unexpected turn to link surrealism and contemporary science (Dialectique 29). ${ }^{25}$ Non-Euclidean geometry, non-Newtonian mechanics and non-Pasteurian biology are all invoked again in Luca's presentation text on the cubomania, while several of the cubomania titles that follow appear to have been sourced from the illustration captions of a popular science manual ("Cubomanies"). With its all-over format, its horror vacui completely covering the ground with found materials, clogging images with multiple horizons and vanishing points, the sense of the cubomania as a familiar yet unknown space full of hitherto invisible energies and matter seems to fill what was once void with a quantum science bent to human desire. The ambition of such claims in contrast to the scale and economy of the cubomania only serves to emphasize the critical weight bearing down on its intensely-focused operation:

La cubomanie est le correspondant oculaire instantané de notre comportement vis-à-vis du monde extérieur, comportement qui consiste dans le refus de regarder comme une réalité objective l'axiomatique condition humaine, même sous ses aspects apparemment immuables. Après notre rencontre avec la géniale découverte de Marx (expression de notre haine critique envers le visage humain difformé par l'économie capitaliste) et après notre rencontre avec la sublime activité de Breton (expression de notre désir sadique de trouver le fonctionnement réel de la pensée), nous complétons notre lucidité théorique et pratique en

\footnotetext{
25 That this connection between surrealism and science is less surprising than at first appears is made clear for the context of French surrealism in Gavin Parkinson's Surrealism, Art and Modern Science; Parkinson describes, for example, how such 'non-' lists are also present in Breton's writings of the late 1930s and 1940s, indebted to Gaston Bachelard for an expression of the "epistemological rupture" sought by surrealist thought (110-11). On Luca's poetry as a form of atom-age science in which phenomena of language are subjected to laboratory testing, see Jouffroy (109-12). One might also note here that Luca had an early background in the study of chemistry.
} 
dénonçant la condition œdipienne de l'existence dans son retour biologiquement réactionnaire vers le passé dans les vestiges castrants, traumatiques et horribles de la naissance, dans son parasitisme sublimal sur les ruines des parents et du frère, dans les traces mnésiques de son double primitif, dans la blessure, la purulente blessure d'Edipe, qui empêche l'homme de trouver les voies exactes de sa libération et après les avoir trouvées, de les maintenir. (“Cubomanies" 277-78)

The cubomania is the instantaneous ocular correspondence of our attitude towards the external world, an attitude consisting in the refusal to see as an objective reality the axiomatic human condition, even in its apparently immutable aspects. After our meeting with Marx's discovery of genius (the expression of our critical hatred directed at the human face distorted by capitalist economy) and after our meeting with the sublime activity of André Breton (the expression of our sadistic desire to find the real functioning of thought), we complete our theoretical and practical lucidity by denouncing the oedipal condition of existence in its biologically reactionary return to the past in the castrating, traumatic and horrible vestiges of birth, in its subliminal parasitism on the ruins of the parents and the brother, in the mnesic traces of its primitive double, in the wound, Oedipus's purulent wound, which prevents humanity from finding the precise paths to its liberation, and after having found them to maintain them.

The cubomania's operation at the intersection of science and eros, of the hyperlogical and the pathological, is underlined by Luca's title for the most extensive publication of his early cubomanias, Les Orgies des quanta (The Quanta Orgies) of 1946 featuring reproductions of thirty-three works, a book whose only text consists of quotes from Hegel and de Sade. ${ }^{26}$ Nevertheless, while Luca and Trost's surrealism might make an appeal to science's 'cryptaesthetic' attraction, what it opposed was its "rigidité mathématique" (Luca and Trost, Dialectique 30) 'mathematical rigidity'. Yet with its formal rigor, its precision cutting, its ruthless geometry, the cubomania itself seems to seek a kind of prime mathematical formula for the restructuring of vision, a passionate and binding equation for the world. A sense of this tension - of mathematics and geometry as something both necessary yet intensely emotional - would resurface much later in Luca's texts for his collaboration of 1966 with Piotr Kowalski for the book-object Sysphe géomètre, in which gas-filled glass geometric solids glow on an electromagnetic plinth. ${ }^{27}$ The definition of Kubos begins: “Corps angoissant / à six faces angoissées / carrées

\footnotetext{
${ }^{26}$ Luca, Les Orgies des quanta. See the discussion on the use of the Hegel quote and Luca's "carnivalesque" dialectics in Carlat (100-01).

27 For a discussion of the work, see Bailly (62-66) and Fijalkowski, "La Poésie sans langue."
} 
angoissantes / égales en angoisse..." (Paralipomènes 102) 'Anguishing body / with six anguishing square / anguished sides / equal in anguish. . . .' ${ }^{28}$ Ever since his first book in French, Quantitativement aimée (Quantitatively Loved), published as a single copy adorned with 944 actual pen nibs, Luca's writings would be obsessed by numbers and counting, a proliferation featured for example in the paranoid enumeration of "Ma déraison d'être" of 1950 in which the poet tries desperately to quantify despair. ${ }^{29}$ A decade later in Paris, Luca's publicity flier for Exactamo ('Maison de mots', a characteristically straight-faced poetic business proposition) promised "l'extraction du carré du mot" "the extraction of the square root of the word' in its offer to locate for its customers the revelatory power of language. ${ }^{30} \mathrm{It}^{\prime} \mathrm{s}$ tempting in turn to read the cubomania as striving for the secret square root of every picture, every representation.

Small as its first step was, limited for the moment to a critical operation on the image, Luca would see the cubomania's non-oedipal logic as not just an expression of a wider attitude to the concrete realm and lived experience, but as itself capable of extension to the rest of the world.

Leçon pratique de cubomanie dans la vie courante: choisissez trois chaises, deux chapeaux, quelques pierres et parapluies, plusieurs arbres, trois femmes nues et cinq très bien habillées, soixante hommes, quelques maisons, des voitures de toutes les époques, des gants, des télescopes, etc.

Coupez tout en petits morceaux (par exemple 6/6 cm.) et mélangez-les bien dans une grande place de la ville. Reconstituez d'après les lois du hasard ou de votre caprice et vous obtiendrez un paysage, un objet ou une très belle femme inconnus ou reconnus, la femme et le paysage de vos désirs. ("Cubomanies" 281)

A practical lesson in cubomania in everyday life: choose three chairs, two hats, several stones and umbrellas, several trees, three naked and three well-dressed women, sixty men, several houses, some cars from each period, some gloves, some telescopes, etc.

\footnotetext{
28 The text of Sisyphe géomètre was republished in Luca, Paralipomènes (102).

${ }^{29}$ The book-object Quantitativement aimée frequently appeared in Luca's lists of his own works, sometimes even fictitiously cited as his "first" publication, but although it has been seen in public (for instance in the exhibition Surrealism: Desire Unbound, Tate Modern 2001), it has remained a legendary, unknown work; see my discussion in "La Poésie sans langue." "Ma déraison d'être" was published in Héros-limite (43-44); a translation and brief discussion of it can be found in "My Unreason of Being."

30 The publicity brochure of 1960 is reproduced in Ghérasim Luca, spec. issue of Cahiers de l'Abbaye Sainte-Croix (7).
} 
Cut everything into little pieces (for example 6 by $6 \mathrm{~cm}$ ) and mix them well in a large city square. Reconstitute them according to the laws of chance or to your whim and you will obtain an unknown or recognized landscape, object or very beautiful woman, the woman and the landscape of your desires.

Brief notations followed this recipe for the cubomania's equivalents in love, sexuality, architecture, painting, dream, and magic. Couched in an ironic, darkly humorous tone reminiscent of Salvador Dali's more provocative texts, with its absurd and excessive list of objects, Luca's promotion of this logic into the realm of things and experience nevertheless gives the cubomania collage the flavor of an action, potential rather than enacted perhaps, but at the same time already lived out everywhere in a world collapsing around the poet's ears. Luca's text of 1947 Le Secret du vide et du plein had cast the dialectical play with words and numbers, thought and desire as a path beyond polarities: "Remplacer le Réel par le Possible et anticiper leur confusion. ... Oublier l'oubli, tripler le double, vider le vide, c'est inventer le plein dans son mouvement. ...” (311) 'Replace the real by the possible and anticipate their confusion. ... To forget forgetting, to triple the double, to void the void, is to invent plenitude in its movement.' As a first demonstration of the power and liberation of non-oedipal thought, the cubomanias of the 1940s present a kind of manifesto for the necessarily devastating transformation of the world.

The cubomanias made from the 1960s until the end of Luca's life toned down this apocalyptic potential, to focus instead on a methodical poetic and philosophical deconstruction of modes of representation, specifically of reproductions of Renaissance and Neoclassical painting (fig. 8). It appears that Luca had temporarily abandoned the format, if not the intellectual positions that underpin it, on leaving Bucharest for Paris via Israel, only for it to resurface with renewed vigor, and more varied appearance, a decade later. ${ }^{31}$ While Luca was less concerned to present these new works within the theoretical context elaborated in Bucharest during the 1940s, they continued to announce a system of probabilities for a lucid, imaginative dismantling and reconstruction of the visual realm, finely balanced between a critical reflection on vision, an unleashing of the hidden signs caught within the mesh of every representation, and the possibility of the extension of a revolutionary desire into the world. From the perspective of studies

31 These post war cubomanias have tended to enjoy greater public exposure, partly through Luca's willingness to display them in a number of group and individual exhibitions, and partly because many of the Bucharest cubomanias either appear to have been lost, or were reproduced only in rarely-seen publications. The later works call for further scholarship and analysis; see Fijalkowski, "La Poésie sans langue" for some further discussion of these collages and exhibitions. 


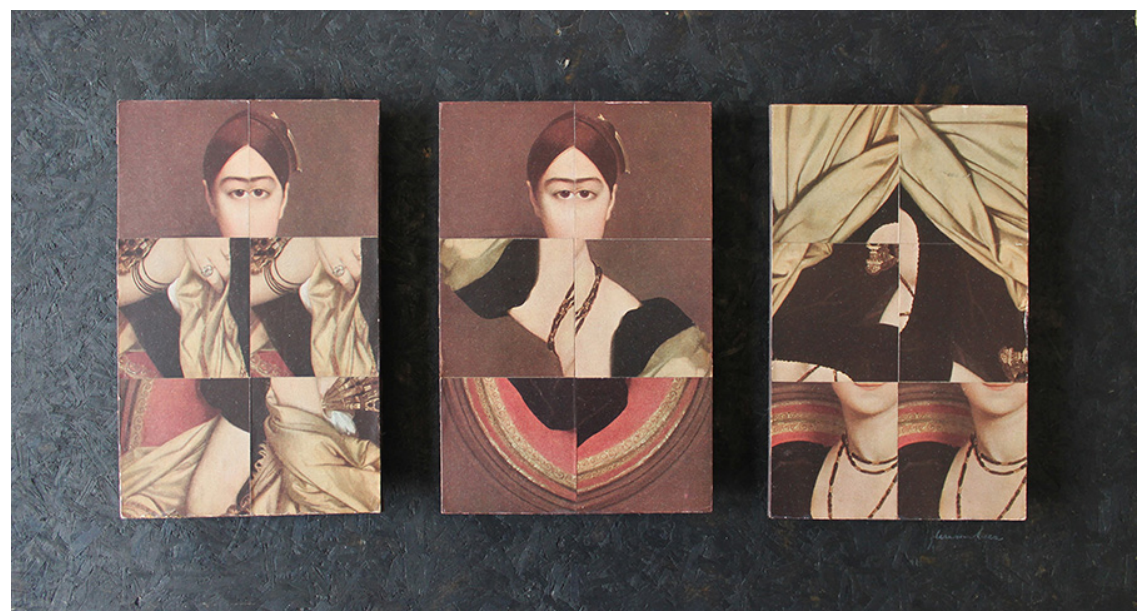

Figure 8: Gherasim Luca, Portrait of Madame Devançay (after Ingres), 1986.

Private collection, Paris. (C) Micheline Catti-Ghérasim Luca.

of surrealism, the cubomania offers a fascinating 'limit case': clearly rooted in surrealist collage of the 1930s, in (dialectical) dialogue with it in fact, yet troubling for the ways in which it appears to promise to systematize and proliferate surrealist practice to an extreme degree even as its context includes a critique of the danger that historical surrealist methodology can turn into recipes and styles. Where can the cubomania lead? The final category of Luca's classification of his collages in the catalogue of January 1945 had proposed 'Sixteen non-oedipal cubomanias with an unknown destination.' Part of the answer to such apparent paradoxes could be the cubomania's tendency to two contrasting impulses, simplicity and secrecy: perhaps one of the most primal of surrealist visual techniques, it has somehow managed to remain all but invisible.

\section{Works Cited}

Adamowicz, Elza. Surrealist Collage in Text and Image: Dissecting the Exquisite Corpse. Cambridge: Cambridge UP, 1998. Print.

Alexandrian, Sarane. Surrealist Art. London: Thames and Hudson, 1970. Print.

Bailly, Jean-Christophe. Piotr Kowalski. Paris: Hazan, 1988. Print.

Bajac, Quentin, et al. La Subversion des images: Surréalisme photographie film. Paris:

Centre Georges Pompidou, 2009. Print.

Bricianer, Serge. "Interview" [with Ghérasim Luca]. Oiseau-Tempête 4 (1998): 32. Print.

Carlat, Dominique. Gherasim Luca l'intempestif. Paris: José Corti, 1998. Print.

Decron, Benoît. "Cubomanies." Ghérasim Luca, Spec. issue of Cahiers de l'Abbaye

Sainte-Croix 35-38. Print. 
Deleuze, Gilles. "Lettres à Ghérasim Luca." Dossier Paul Célan Ghérasim Luca. Spec. issue of Cahier critique de poésie 17 (2008): 73-76. Print.

Deleuze, Gilles, and Félix Guattari. L'Anti-CEdipe: Capitalisme et schizophrénie. Rev.ed. Paris: Minuit, 1980. Print.

Durozoi, Gérard. History of the Surrealist Movement. Chicago: U of Chicago P, 2002. Print.

Eburne, Jonathan P. "'Comme une erosion unique': Les Provocations d'Infranoir." Yaari, Monique, ed., "Infra-Noir" 33-35. Print.

Ernst, Max. "Inspiration to Order". Beyond Painting. New York: Wittenborn Schulz, 1948. 20-25. Print.

Fijalkowski, Krzysztof. "From Sorcery to Silence: The Objects of Gherasim Luca." Modern Language Review 88.3 (1993): 625-38. Print. $<$ http://dx.doi.org/10.2307/3734930>

—. "Gherasim Luca: Reinvent Everything." Phosphor 3 (2011): 3-11. Print.

—. "La Poésie sans langue: Ghérasim Luca, Visual Poet." Hyperion 7.2 (2013). Web. 31 Aug. 2013. <http://issuu.com/contramundum/docs/hyp-lucafull issue-2013/13>.

Gherasim Luca. "Cubomanies." Luca and Trost, Présentation de graphies colorées. 1945. Yaari, Monique, ed., "Infra-Noir" 277-82. Print.

- Héros-limite. Paris: Soleil noir, 1953. Print.

- Inventatorul iubirii. 1945. Inventatorul iubirii şi alte scrieri. Ed. Ion Pop. Cluj-Napoca: Dacia, 2003. 230-40. Print. Avangarda.

- The Inventor of Love. Trans. Julian and Laura Semilian. Boston: Black Widow P, 2009. Print.

—. Letter to Jacques Hérold, Tel Aviv 5 April 1951. Collection Jacques Hérold. Sale catalogue. Paris Drouot Richelieu, 13 November 1998, lot 188. Print.

—. "My Unreason of Being." Phosphor 3 (2011): 12-13. Print.

- Les Orgies des quanta. Bucharest: Surréalisme, 1946. Print.

- Paralipomènes. Paris: Soleil Noir, 1976. Print.

- The Passive Vampire. Trans. Krzysztof Fijalkowski. Prague: Twisted Spoon P, 2008. Print.

- Le Secret du vide et du plein. 1947. Yaari, Monique, ed., "Infra-Noir" 31017. Print.

- Self-Shadowing Prey. New York: Contra Mundum P, 2013. Print.

_. Le Vampire passif. Paris [i.e. Bucharest]: Éditions de l'Oubli, 1945. Rev. ed. Paris: José Corti, 2001. Print.

Gherasim Luca, Gilles Ehrmann, and Micheline Catti. Crier taire sourire fou: Éclairage du double reglé par Gherasim Luca, Gilles Ehrmann et Micheline Catti. Hand-drawn calligraphy by Pierre Boutillier. Paris: n.p., 1961. Print.

Gherasim Luca and Piotr Kowalski. Sisyphe géomètre. Geneva: Claude Givaudan, 1966. Print/Sculpture. 
Gherasim Luca, Gellu Naum, Paul Păun, Virgil Teodorescou, and Trost. L'Infranoir: Préliminaires à une intervention sur-thaumaturgique dans la conquête $d u$ desirable. Yaari, Monique, ed., "Infra-Noir" 289-99. Print.

—. "Le Sable nocturne." Le Surréalisme en 1947. Paris: Maeght, 1947. 56-58. Print.

Gherasim Luca and Trost. "Dialectics of the Dialectic." Surrealism Against the Current: Tracts and Declarations. Ed. Michael Richardson and Krzysztof Fijalkowski. London: Pluto, 2001. 32-41. Print.

—. Dialectique de la Dialectique: Message addressé au mouvement surréaliste international. Bucharest: Surréalisme, 1945. Print.

- Présentation de graphies colorées, de cubomanies et d'objets. 1945. Yaari, Monique, ed., "Infra-Noir" 270-84. Print.

Ghérasim Luca. Spec. issue of Cahiers de l'Abbaye Sainte-Croix 110 (2008). Print.

Gibus, Aurélia. “Ghérasim Luca et les livres." Cahiers de l'Abbaye Sainte-Croix 110 (2008): 29-32. Print.

—. "Ghérasim Luca et les livres." 2 vols. MA thesis. Université Paris Ouest, 2006. Print.

—. "Parcourir 1'impossible: La Construction du surréalisme en Roumanie." 2 vols. MA thesis. Université Paris Ouest, 2007. Print.

Huizinga, Johan. Homo Ludens: A Study of the Play-Element in Culture. London: Routledge, 2003. Print.

Jouffroy, Alain. La Fin des alternances. Paris: Gallimard, 1970. Print.

Krauss, Rosalind. "Grids." The Originality of the Avant-Garde and Other Modernist Myths. Cambridge, MA: MIT P, 1985. 8-22. Print.

Krebs, Constance, ed. André Breton. Association Atelier André Breton, 2003. 10 May 2013. Web. <http://www.andrebreton.fr/>.

Manucu, Nicoleta. "Luca ou l'invention du soi." Cahiers de l'Abbaye Sainte-Croix 110 (2008): 9-16. Print.

Martin, Serge. "S'asseoir sans chaise avec les cubomanies et les ontophonies de Ghérasim Luca." Diérèse 46 (2009): 171-86. Print.

Morando, Camille, and Sylvie Patry, eds. Victor Brauner: Écrits et correspondances 1938-1948. Paris: Centre Georges Pompidou, 2005. Print.

Orlandi, Sibylle. "Les cubomanies de Ghérasim Luca: Dispositif sémiotique et métalangage visuel." MA thesis. École Normale Supérieure de Lyon, Université de Lyon II, 2012. Print

Parkinson, Gavin. Surrealism, Art and Modern Science. New Haven: Yale UP, 2008. Print.

Pohribny, Arsén. “The Legacy of the Weeks of 1968." Jiří Kolář: Diary 1968. Ed. David Elliott and Arsén Pohribny. Oxford: Museum of Modern Art, 1984. 720. Print.

Raileanu, Petre. Gherasim Luca. Paris: Oxus, 2004. Print.

Toma, Iulian. Gherasim Luca ou l'intransigeante passion d'être. Paris: Champion, 2013. Print. 
Trost. "Graphies colorées." Luca and Trost, Présentation de graphies colorées. 1945. Yaari, Monique, ed., "Infra-Noir" 272-76. Print.

Tzara, Tristan. "Dada Manifesto of Feeble Love and Bitter Love." Seven Dada Manifestoes and Lampisteries. London: Calder, 1977. 31-48. Print.

Waara, Richard. "Metamorphosis of a Moorish Nude Postcard." Hydrolith: Surrealist Research and Investigations. Berkeley: Oyster Moon P, 2010. 83-88. Print.

Yaari, Monique, ed. "Infra-Noir", un et multiple: Un groupe surréaliste entre Bucarest et Paris, 1945-1947. Oxford: Peter Lang, 2014. Print.

Copyright @ 2015 Krzysztof Fijalkowski 